\title{
KARAKTERISTIK IBU KAITANNYA DENGAN KEJADIAN BAYI BERAT BADAN LAHIR RENDAH
}

\author{
Supiati \\ Kementerian Kesehatan Politeknik Kesehatan Surakarta Jurusan Kebidanan
}

\begin{abstract}
Age, Parity, Incidence of $\mathbf{L B W}$. One indicator to determine the degree of public health is the infant mortality rate (IMR). Infant mortality rate in Indonesia is still relatively high, which recorded 31 per 1,000 live births in 2008. This study aims to determine the relationship between maternal age and parity with $L B W$ in the Maternity Hospital (RB) Juweni Village Pandes Wedi Klaten This study uses descriptive analytic correlation with retrospective approach. The study population all mothers delivered in January 2011-September 2012 with a total population of 142 mothers. The study was conducted in October 2012. The results of the study obtained the highest maternal age age is not at risk of 124 respondents (87.3\%), most mothers Parity multi 75 respondents (52.8\%), the highest incidence of low birth weight is not 133 respondents (93.7\%). It can be concluded that there is no relationship between the age of mothers with $L B W$ and there is no relationship between the parity of mothers with $L B W$.
\end{abstract}

Keywords: Age, Parity, Incidence of $L B W$.

Abstrak: Umur, Paritas, Kejadian BBLR. Salah satu indikator untuk mengetahui derajat kesehatan masyarakat adalah Angka Kematian Bayi (AKB). Angka Kematian Bayi di Indonesia saat ini masih tergolong tinggi, yaitu tercatat 31 per 1000 kelahiran hidup pada tahun 2008. Penelitian ini bertujuan mengetahui hubungan antara umur dan Paritas ibu dengan kejadian BBLR di Rumah Bersalin (RB) Juweni Desa Pandes Wedi Klaten Penelitian ini menggunakan metode diskriptif analitik korelasi dengan pendekatan retrospektif. Populasi penelitian semua ibu yang bersalin bulan Januari 2011-September 2012 dengan total populasi sebanyak 142 ibu. Penelitian dilakukan pada bulan Oktober 2012. Hasil Penelitian didapat umur ibu terbanyak umur tidak beresiko 124 responden $(87,3 \%)$, Paritas ibu terbanyak multi 75 responden (52,8\%), Angka kejadian BBLR terbanyak tidak 133 responden (93,7\%). Dapat disimpulkan bahwa tidak ada hubungan antara umur ibu dengan kejadian BBLR dan tidak ada hubungan antara paritas ibu dengan kejadian BBLR.

Kata Kunci: Umur, Paritas, Kejadian BBLR.

PENDAHULUAN

Salah satu indikator untuk mengetahui derajat kesehatan masyarakat adalah Angka Kematian Bayi (AKB). Angka Kematian Bayi di Indonesia saat ini masih tergolong tinggi, yaitu tercatat 31 per 1000 kelahiran hidup pada tahun 2008, ini memang bukan gambaran yang indah, karena masih terbilang tinggi bila di bandingkan dengan negara-negara di bagian ASEAN dan penyebab kematian bayi terbanyak adalah karena gangguan perinatal. Dari seluruh kematian 
perinatal sekitar 2-27\% disebabkan karena BBLR. Sementara itu, prevelensi BBLR di Indonesia saat ini diperkirakan $7-14 \%$ yaitu sekitar 459.200-900.000 bayi. (Depkes RI, 2008). Masalah berat badan lahir rendah (BBLR) sampai saat ini masih merupakan penyebab utama morbiditas dan mortalitas perinatal. Menurut Survei Demografi dan Kesehatan Indonesia (SDKI) tahun 2007 bahwa angka kematian neonatal sebesar 19 per 1.000 kelahiran hidup berarti bahwa dalam 1 tahun, sekitar 86.000 bayi usia 1 bulan meninggal atau setiap 6 menit ada 1 (satu) neonatus meninggal. Data dari Rumah Sakit Pusat Rujukan didapat sekitar $15-20 \%$ (UKK Perinatologi) bayi dilahirkan dengan berat badan lahir rendah sedangkan jumlah kelahiran BBLR secara nasional adalah 11,5\% (Rikesda, 2007). Sebagian besar BBLR $<2000$ gram meninggal pada masa neonatal. Kematian neonatal, digolongkan menjadi 2 yaitu kematian neonatal $(0-$ 28 hari) dan kematian post natal (29 hari - 1 tahun). Pola penyakit penyebab kematian menunjukkan bahwa proporsi penyebab kematian neonatal tertinggi adalah berat badan lahir rendah (BBLR) selain asfiksia lahir dan infeksi (tetanus neonaturom, sepsis, pneumonia, diare) kemudian feeding problem (Sarimawar, 2003).

BBLR dibedakan dalam 2 kategori yaitu : BBLR karena prematur (usia kandungan kurang dari 7 minggu) dan BBLR karena intra uterine growth retardation (IUGR) yaitu bayi cukup bulan tetapi berat kurang untuk usianya. Kebanyakan BBLR di negara berkembang dengan IUGR sebagai akibat ibu dengan status gizi buruk, anemia, malaria, dan menderita penyakit menular seksual (PMS) sebelum konsepsi atau ketika hamil (Sarimawar, 2003). Perawatan BBLR memerlukan perawatan secara intensif dengan cara mempertahankan suhu tubuh untuk mencegah terjadinya hipotermi, mencegah infeksi, dan memberikan nutrisi / ASI dilakukan dengan baik karena reflek menelan BBLR belum sempurna. Dengan dilakukan perawatan yang intensif terhadap BBLR diharapkan keadaan bayi menjadi lebih baik (Wiknjosastro, 2010).

Adapun faktor-faktor yang menyebabkan terjadinya BBLR/ persalinan preterm (prematur) adalah 1) Faktor ibu yang meliputi gizi saat hamil yang kurang, umur ibu kurang dari 20 tahun/ di atas 35 tahun, jarak kehamilan dan bersalin terlalu dekat, penyakit menahun ibu seperti hipertensi, jantung, pembuluh darah, dan faktor pekerjaan terlalu berat, 2) Faktor kehamilan yaitu dengan hidroamnion, hamil ganda, perdarahan antepartum, komplikasi hamil seperti preeklampsial eklampsia, ketuban pecah dini, 3) Faktor janin yaitu cacat bawaan dan infeksi dalam rahim dan 4) Faktor yang masih belum diketahui (Manuaba, 1998).

Berdasarkan survey pendahuluan yang dilakukan pada 7 ibu yang melahirkan tanggal 17 - 21 September 2012 didapat jumlah bayi yang lahir dengan berat badan lahir rendah adalah 4 bayi dengan umur ibu $19-28$ tahun dan paritas $>2$.

\section{METODE PENELITIAN}

Penelitian adalah diskriptif analitik korelasi karena menganalisis ada hubungan antara umur dan Paritas ibu dengan kejadian Berat Badan Lahir Rendah di Rumah Bersalin (RB) Juweni Desa Pandes Wedi Klaten 
tahun 2012. Pendekatan retrospektif adalah meneliti kebelakang dengan menggunakan data sekunder untuk melihat apakah ada hubungan atau tidak.

Populasi adalah semua ibu yang bersalin di Rumah Bersalin (RB) Juweni Desa Pandes Wedi Klaten pada bulan Januari 2011-September 2012 sebanyak 142 ibu dengan teknik pengambilan sampel secara total populasi yaitu semua populasi dijadikan sampel yaitu $142 \mathrm{ibu}$.

Variabel dalam penelitian ini variabel bebas adalah umur dan paritas dan variabel terikat adalah kejadian BBLR. Teknik pengumpulan data dalam penelitian ini adalah dengan menggunakan data sekunder diperoleh melalui data dari dokumetasi (kohort) tentang umur ibu, paritas ibu, kejadian BBLR di RB Juweni pada bulan Januari 2011- September 2012.

\section{HASIL PENELITIAN}

Penelitian ini dilakukan di Rumah Bersalin (RB) Juweni Desa Pandes Wedi Klaten bulan Oktober 2012 pada 142 ibu untuk mengetahui hubungan antara umur dan Paritas ibu dengan kejadian BBLR.

\section{Analisa univariate}

\section{Tabel 1}

Distribusi Responden Berdasarkan

\begin{tabular}{lcc}
\multicolumn{4}{c}{ Umur ibu } \\
\hline \multicolumn{1}{c}{ Umur } & $\mathrm{f}$ & $\%$ \\
\hline $\begin{array}{l}\text { Resiko }:<20 \text { atau }>35 \\
\text { tahun }\end{array}$ & 18 & 12.7 \\
$\begin{array}{l}\text { Tidak beresiko: } 20-35 \\
\text { tahun }\end{array}$ & 124 & 87.3 \\
\hline \multicolumn{1}{c}{ Jumlah } & 142 & 100 \\
\hline
\end{tabular}

Berdasarkan tabel 1 distribusi responden berdasarkan umur ibu didapat yang terbanyak umur tidak beresiko sebanyak 124 responden $(87,3 \%)$.
Tabel 2

Distribusi Responden Berdasarkan paritas ibu

\begin{tabular}{|c|c|c|}
\hline Paritas & f & $\%$ \\
\hline Primi & 62 & 43.7 \\
\hline Multi & 75 & 52.8 \\
\hline Grande multi & 5 & 3.5 \\
\hline Jumlah & 142 & 100 \\
\hline
\end{tabular}

Berdasarkan tabel 2 distribusi responden berdasarkan paritas ibu didapat yang terbanyak paritas terbanyak multi sebanyak 75 responden $(52,8 \%)$.

Tabel 3

Distribusi angka kejadian BBLR

\begin{tabular}{|c|c|c|}
\hline Angka Kejadian BBLR & $\mathbf{F}$ & $\%$ \\
\hline $\mathrm{Ya}$ & 9 & 6.3 \\
\hline Tidak & 133 & 93.7 \\
\hline Jumlah & 142 & 100 \\
\hline
\end{tabular}

Berdasarkan tabel 3 distribusi angka kejadian BBLR didapat yang terbanyak tidak yaitu 133 responden $(93,7 \%)$.

\section{Analisa Bivariat}

Tabel 4

Hubungan antara umur ibu bersalin dengan kejadian BBLR

\begin{tabular}{cccc}
\hline \multirow{2}{*}{ Umur } & \multicolumn{3}{c}{ Kejadian BBLR } \\
\cline { 2 - 4 } Ya & Tidak & Jumlah \\
\hline Resiko & 2 & 16 & 18 \\
& $(1,4 \%)$ & $(11,3 \%)$ & $(12,7 \%)$ \\
Tidak & 7 & 117 & 124 \\
beresiko & $(4,9 \%)$ & $(82,4 \%)$ & $(87,3 \%)$ \\
\hline Jumlah & 9 & 133 & 142 \\
& $(6,3 \%)$ & $(93,7 \%)$ & $(100 \%)$ \\
\hline
\end{tabular}

Berdasarkan tabel 44 didapat umur dengan kejadian BBLR terbanyak adalah umur tidak beresiko dengan tidak kejadian BBLR sebanyak 117 responden $(82,5 \%)$.

Berdasarkan hasil perhitungan umur dengan kejadian BBLR dengan menggunakan uji chi square $\left(\mathrm{x}^{2}\right)$ didapat hasil Asympt.sig yaitu 0,734 yang berarti $p>0,05$ atau $0,734>0,05$ berarti tidak ada hubungan antara umur 
ibu bersalin dengan kejadian BBLR di Rumah Bersalin (RB) Juweni Desa Pandes Wedi Klaten tahun 2012.

\section{Tabel 5}

Hubungan antara paritas ibu bersalin dengan kejadian BBLR

\begin{tabular}{cccc}
\hline \multirow{2}{*}{ Paritas } & \multicolumn{3}{c}{ Kejadian BBLR } \\
\cline { 2 - 4 } Ya & Tidak & Jumlah \\
\hline \multirow{3}{*}{ Pulti } & 6 & 56 & 62 \\
& $(4,2 \%)$ & $(39,4 \%)$ & $(43,7 \%)$ \\
Grande & $(2,1 \%)$ & 72 & 75 \\
& 0 & $50,7 \%)$ & $(52,8 \%)$ \\
& $(0 \%)$ & $(3,5 \%)$ & 5 \\
Jumlah & 9 & $133,6 \%)$ \\
& $(6,3 \%)$ & $(93,7 \%)$ & $(100 \%)$ \\
\hline
\end{tabular}

Berdasarkan tabel 5 didapat paritas dengan kejadian BBLR terbanyak adalah paritas multi dengan tidak kejadian BBLR sebanyak 72 responden $(50,7)$. Berdasarkan hasil perhitungan paritas dengan kejadian BBLR dengan menggunakan uji chi square $\left(\mathrm{x}^{2}\right)$ didapat hasil Asympt.sig yaitu 0,334 yang berarti $p>0,05$ atau $0,334>0,05$ berarti tidak ada hubungan antara paritas ibu bersalin dengan kejadian BBLR di Rumah Bersalin (RB) Juweni Desa Pandes Wedi Klaten tahun 2012.

\section{PEMBAHASAN}

Berdasarkan tabel 1 distribusi responden berdasarkan umur ibu di Rumah Bersalin (RB) Juweni Desa Pandes Wedi Klaten tahun 2012 didapat yang terbanyak umur tidak beresiko sebanyak 124 responden (87,3\%). Hal ini tidak sesuai dengan pendapat Manuaba (1998) bahwa faktor yang menyebabkan terjadinya BBLR adalah umur ibu $<20$ tahun atau $>35$ tahun (umur beresiko).

Berdasarkan tabel 2 distribusi responden berdasarkan paritas ibu di Rumah Bersalin (RB) Juweni Desa Pandes Wedi Klaten tahun 2012 didapat yang terbanyak paritas terbanyak multi sebanyak 75 responden $(52,8 \%)$. Hal ini sesuai dengan pendapat Prawiroharjo (2006) bahwa paritas 1 dan 3 adalah paritas yang aman untuk hamil dan bersalin dan didukung pendapat dari Manuaba (1998) ibu dengan paritas> 3 (beresiko) tidak aman dan lebih sering melahirkan BBLR, Hal tersebut dimungkinkan alat-alat Reproduksi yang sudah menurun, dan sel-sel otot yang mulai melemah sehingga ibu dengan paritas beresiko cenderung melahirkan BBLR

Berdasarkan tabel 3 distribusi angka kejadian BBLR di Rumah Bersalin (RB) Juweni Desa Pandes Wedi Klaten tahun 2012 didapat yang terbanyak tidak yaitu 133 responden (93,7\%). Menurut Amiruddin (2007) kejadian BBLR di pengaruhi oleh beberapa faktor yaitu faktor-faktor yang berasal dari ibu meliputi : umur ibu, umur kehamilan, paritas, berat badan dan tinggi badan, status gizi (nutrisi), kebiasaan minum alkohol dan merokok, penyakit-penyakit keadaan tertentu waktu hamil (anemia, perdarahan dan lain-lain), jarak kehamilan, kehamilan ganda, riwayat abortus. Faktor yang berasal dari janin meliputi : kehamilan kembar dan kelainan bawaan. Faktor lingkungan seperti pendidikan dan pengetahuan ibu, pekerjaan status sosial ekonomi dan budaya, dan faktor pelayanan kesehatan.

Berdasarkan hasil perhitungan umur dengan kejadian BBLR dengan menggunakan uji chi square $\left(\mathrm{x}^{2}\right)$ didapat hasil Asympt.sig yaitu 0,734 yang berarti $p>0,05$ atau $0,734>0,05$ berarti tidak ada hubungan antara umur ibu bersalin dengan kejadian BBLR di Rumah Bersalin (RB) Juweni Desa Pandes Wedi Klaten tahun 2012. 
Penelitian ini sesuai dengan Joni (2008) bahwa tidak ada hubungan usia ibu dengan kejadian BBLR. Lain halnya pendapat Wiknjosastro (2010) faktor- faktor yang mempengaruhi bayi berat badan lahir rendah adalah : Faktor Ibu, meliputi umur ibu kurang dari 20 tahun atau lebih dari 35 tahun.

Berdasarkan hasil perhitungan paritas dengan kejadian BBLR dengan menggunakan uji chi square $\left(\mathrm{x}^{2}\right)$ didapat hasil Asympt.sig yaitu 0,334 yang berarti $p>0,05$ atau $0,334>0,05$ berarti tidak ada hubungan antara paritas ibu bersalin dengan kejadian BBLR di Rumah Bersalin (RB) Juweni Desa Pandes Wedi Klaten tahun 2012. Penelitian ini sesuai dengan Joni (2008) bahwa tidak ada hubungan paritas ibu dengan kejadian BBLR. Hal ini berbeda dengan pendapat Rochyati (2003) bahwa ibu yang melahirkan dengan paritas 1 dan $\geq 4$ lebih banyak di bandingkan dengan paritas 2-3. Pada ibu dengan paritas 1, sebagian besar ibu belum siap secara fisik maupun mental dalam menjalani kehamilannya, sedangkan pada paritas $\geq 4$ ibu telah banyak melahirkan yang menyebabkan ibu mengalami kemunduran pada fungsi organ pada fungsi organ reproduksinya.

\section{KESIMPULAN DAN SARAN}

Berdasarkan hasil penelitian yang dilakukan pada 142 responden bulan Oktober 2012 di Rumah Bersalin (RB) Juweni Desa Pandes Wedi Klaten tahun 2012 dapat disimpulkan

1. Umur ibu terbanyak umur tidak beresiko sebanyak 124 responden $(87,3 \%)$.

2. Paritas ibu terbanyak multi sebanyak 75 responden $(52,8 \%)$.

3. Angka kejadian BBLR terbanyak tidak yaitu 133 responden $(93,7 \%)$.
4. Tidak ada hubungan antara umur ibu dengan kejadian BBLR di Rumah Bersalin (RB) Juweni Desa Pandes Wedi Klaten tahun 2012.

5. Tidak ada hubungan antara paritas ibu dengan kejadian BBLR di Rumah Bersalin (RB) Juweni Desa Pandes Wedi Klaten tahun 2012.

\section{DAFTAR RUJUKAN}

Departemen Kesehatan Republik Indonesia. (2008). Angka kematian Ibu dan Bayi. Depkes RI, Jakarta

Departemen Kesehatan Republik Indonesia. (2008). Tetanus Neonatorum dan Bayi Berat Lahir Rendah. Depkes RI, Jakarta

Joni, Meidrin (2008). Hubungan usia ibu dan paritas dengan kejadian BBLR pada bayi baru lahir di RSUD H. Hanafie Bungo tahun 2008. Jurnal SUPTAKBPP. VOL. I NO. 2 TAHUN 2008

Manuaba, Ida Bagus. (1998). Ilmu Kebidanan Penyakit Kandungan dan KB untuk Bidan, ECG. Jakarta.

Prawiroharjo, S. (2006). Buku Acuan Nasional Pelayanan Kesehatan Maternal dan Neonatal. Jakarta : Yayasan Balai Pustaka Sarwono Prawirohardjo.

Rochyati, P., (2003). Skrining Antenatal pada Ibu Hamil, Airlangga University Press,, Surabaya.

Sarimawar, Djaja, (2003). Penyakit Penyebab Kematian BBL dan Sistem Pelayanan Kesehatan yang berkaitan di Indonesia (www.sarimdlitbang.depkes.go.

id.) (Diakses tanggal 2 September 2012).

Wiknjosastro, Hanifa. (2010). Ilmu Kebidanan. Jakarta : Yayasan Bina Pustaka Sarwono Prawirodiharjo. 